2nd option, $Q_{\text {bal }}$ value depending on the height $y$

\begin{tabular}{|c|c|c|}
\hline Height $\mathbf{y}, \mathbf{m}$ & Width and length $\mathbf{x}, \mathbf{m}$ & Heat loss $\mathbf{Q}_{\text {bal }}, \mathbf{W}$ \\
\hline 1 & 1 & 18,154 \\
\hline 0,9 & 1,0541 & 18,302 \\
\hline 0,8 & 1,118 & 18,6 \\
\hline 0,7 & 1,1952 & 19,122 \\
\hline 0,6 & 1,291 & 19,991 \\
\hline 0,5 & 1,4142 & 21,43 \\
\hline 0,4 & 1,5811 & 23,894 \\
\hline 0,3 & 1,8257 & 28,457 \\
\hline 0,2 & 2,2361 & 38,378 \\
\hline 0,1 & 3,1623 & 70,103 \\
\hline
\end{tabular}

\title{
References:
}

1. Beckman, N.G., Gilli, P. (1987). Thermal energy storage. Moscow: World.

2. Duffy, J. A., Beckman, W. A. (1977). Thermal processes using solar energy. Moscow: World.

3. Anderson B. Solar Energy (1982). Fundamentals of building design. Moscow: Stroiizdat.

\section{APPEARANCE OF TURBIDITY IN ALCOHOLIC BEVERAGES}

\section{Oleksandr Ostryk ${ }^{1}$ \\ Svitlana Oliynyk ${ }^{2}$}

DOI: https://doi.org/10.30525/978-9934-588-11-2_12

Transparency of alcohols is one of the main components of their presentation. Thus predicting the resistance to different types of turbidity is their important quality indicator.

Alcoholic beverages should meet the requirements of the national standards according to organoleptic, physico-chemical parameters and the expiration date, which is established after determining the projected resistance. The expiration date of alcoholic beverages should not exceed their predicted resistance. In this regard, manufacturers are demanding heigh quality and following technological modes of processing raw materials, semi-finished products and beverages in order to achieve their guaranteed stability.

However, while storing the alcoholic beverages may not last the expiration dates, they attain turbidity, color changes, sediments. Turbidity is produced in alcoholic

\footnotetext{
${ }^{1}$ National University of Food Technology, Ukraine

${ }^{2}$ National University of Food Technology, Ukraine
} 
beverages has physico-chemical nature and can be classified as protein, polysaccharide, phenolic, metallic, etc. [1, p. 73].

Colloidal sediments are usually associated with the condensation of phenolic substances. During the technological stages of beverages making of berry semi-finished products phenolic substances are oxidized, as a result the intensity of color may vary in the finished product. Leucanthocyanins may also change the color of both semi-finished and finished beverages. The degree of color intensity change depends on the type of semi-finished product and the phenolic substances in it [1, p. 71].

Turbidity appears in alcoholic beverages, which do not go through the stage of long-term maturing, that's why to prevent condensation one has to create optimal conditions for the timely oxidation processes.

When grinding fruit and berry raw materials during the fruit or juices alcohols making, water-soluble polysaccharides appear in the liquid phase. This leads to the possibility of colloidal turbidity occurrence.

The resistance of beverages made of berry raw materials is also effected by Calcium, magnesium, iron, and potassium salts which lead to the formation of sediments of different colors [2, p. 39].

A research has made to establish the technological methods of stabilization of different groups of alcoholic beverages, to find out their projected resistance, to identify the sources and crystalline sediments.

As a result of alcoholic beverages research, a variety of crystalline sediments by size, color, and shape has been established. The qualitative reactions and the method of capillary electrophoresis determined the composition of the crystalline sediment microcomponents, which include ions of calcium, sodium, potassium, iron, sulfates, phosphates, oxalates, citrates. Their qualitative and quantitative composition is determined by technological features of alcoholic beverages production: the quality of fruit drinks and alcoholic fruit and berry extracts, alcoholic juices, alcoholic tinctures of herbal raw materials, prepared water, sugar-containing substances, colors, ingredients, regulating acids.

The usage of prepared water in making alcohol beverages, with a hardness of more than $0.1 \mathrm{~mol} / \mathrm{dm} 3$ and a sulfate content of more than $50 \mathrm{mg} / \mathrm{dm} 3$, phosphates of more than $0.05 \mathrm{mg} / \mathrm{dm} 3$, silicates of more than $5.0 \mathrm{mg} / \mathrm{dm} 3$ leads to sedimentation, including calcium and magnesium pectate. Iron and manganese compounds, with their content in water exceeding $0.05 \mathrm{mg} / \mathrm{dm} 3$, reacting with the tannin substances in alcoholic juices and fruit drinks, cause the turbidity of the beverages and the formation of sediments.

Sugar color and sugar syrup are also capable of enriching alcoholic beverages with calcium, sodium and ammonium cations, phosphates, oxalates.

Other causes of sediment formation in finished drinks may also be:

- the use of water or water-alcohol mixture of silver-impregnated cartridge filters for additional filtration,

- no additional processing of honey aqua-alcoholic solutions,

- lack of testing before blending and additional processing of essential oils and alcoholic herbal tinctures, 
- the wrong turn of blending ingredients and semi-finished products,

- irrational ways of blend stabilization before filtering,

- insufficient maturing of the blend,

- the use of raw filter paper for blend filtration etc.

Longer expiration dates of tinctures can be obtained by increasing the resistance due to multi-stage processing: on the processing stages of each semi-finished product and the following processing of the finished blend.

\section{References:}

1. Sergeeva, I.Y. Classification of components of opacities of drinks from plant materials. Technique and technology of food production. 2016. T. 42. No. 3. Pp. 70-76.

2. Polyakova I.V. Methods for stabilizing alcoholic beverages. [Text] I.V. Polyakova, A.B. Danilovtseva, V.V. Zhirova, A.L. Panasyuk // Sat. tr IX Int. scientific and practical. conf. «Strategy for the development of the food industry». Moscow: MGUTU, 2003. Pp. 39-41.

\section{METHOD TO IMPROVE OF RELIABILITY AND SERVICE LIFE GROWTH FOR OPEN GEAR DRIVE}

\section{Anton Riazantsev ${ }^{1}$}

DOI: https://doi.org/10.30525/978-9934-588-11-2_13

Gear drive takes the leading place in mechanical systems (machines and mechanisms) and the industrial safety and output quality depends on its current technical condition. They are operated in conditions of impulsive-cyclic subgrade loads, which cause high requirements for the loadbearing of gear drive. Reduction of loadbearing is determined by such reasons as: weakening of the tooth at its base, fatigue spalling of contact point and wear of tooth profile.

For increase of reliability of gear and transmission it is of current interest the following: development of scientifically grounded and proved evaluation criteria for limit state of gear drive; development of methodology for operational evaluation of wear rate of teeth working area; improvement of technology of their case-hardening.

Researches concerning determination of common patterns of abrasive wear are the most interesting. The range of works in this direction is based on the usage of theory of similarity. Researches based on the study of abrasive grain mechanic in the zone of teeth contact (Gavrilenko V.A., Ermichev V.A., Kashcheev V.N.) are of great interest. Data of the work is further developed by G.Ya. Yampol'skiy, A.P. Natarov, I.V. Kragel'skiy [1;2; 3; 4].

Exploitation experience and experimental research show that service life of rim is determined by economic aspect, not physical capacity. At certain value of rim wear, service life of gear wheel reduces insomuch that its further exploitation does not

\footnotetext{
${ }^{1}$ Kryvyi Rih National University, Ukraine
} 